\title{
Author Correction: Towards a data-integrated cell
}

\author{
Noël Malod-Dognin ${ }^{1,2}$, Julia Petschnigg 1 , Sam F.L. Windels ${ }^{1}$, Janez Povh ${ }^{3}$, Harry Hemingway ${ }^{4,5,6}$, \\ Robin Ketteler (10 ${ }^{7}$ \& Nataša Pržulj ${ }^{1,2,8}$
}

Correction to: Nature Communications https://doi.org/10.1038/s41467-019-08797-8, published online 18 February 2019.

The original version of this Article contained an error in the spelling of the author Harry Hemingway, which was incorrectly given as Harry Hemmingway. This has been corrected in both the PDF and HTML versions of the Article.

Published online: 21 May 2019

\begin{abstract}
(c) Open Access This article is licensed under a Creative Commons Attribution 4.0 International License, which permits use, sharing, adaptation, distribution and reproduction in any medium or format, as long as you give appropriate credit to the original author(s) and the source, provide a link to the Creative Commons license, and indicate if changes were made. The images or other third party material in this article are included in the article's Creative Commons license, unless indicated otherwise in a credit line to the material. If material is not included in the article's Creative Commons license and your intended use is not permitted by statutory regulation or exceeds the permitted use, you will need to obtain permission directly from the copyright holder. To view a copy of this license, visit http://creativecommons.org/licenses/by/4.0/.
\end{abstract}

(c) The Author(s) 2019

\footnotetext{
${ }^{1}$ Department of Computer Science, University College London, London WC1E 6BT, UK. ${ }^{2}$ Department of Life Science, Barcelona Supercomputing Center (BSC), Barcelona 08034, Spain. ${ }^{3}$ Faculty of Mechanical Engineering, University of Ljubljana, Ljubljana 1000, Slovenia. ${ }^{4}$ Health Data Research UK London, University College London, London WC1E 6BT, UK. ${ }^{5}$ Institute of Health Informatics, University College London, London WC1E 6BT, UK. ${ }^{6}$ The National Institute for Health Research University College London Hospitals Biomedical Research Centre, University College London, London W1T 7DN, UK. ${ }^{7}$ MRC Laboratory for Molecular Cell Biology, University College London, London WC1E 6BT, UK. ${ }^{8}$ ICREA, Pg. Lluís Companys 23, 08010 Barcelona, Spain. Correspondence and requests for materials should be addressed to N.P. (email: natasa@cs.ucl.ac.uk)
} 